\title{
Synthesis and Characterization of Mononuclear Octahedral Fe(III) Complex Containing a Biomimetic Tripodal Ligand, $N$-(Benzimidazol-2-ylmethyl)iminodiacetic Acid
}

\author{
Dohyun Moon. Junghyun Kim, and Myoung Soo Lah" \\ Deparment of Chemistry and Applied Chemistry, Hanyang University, Ansan, Kynggi 426-791, Korea \\ "E-mail: mslah@hanyang.ac.kr \\ Received Jine 7, 2006
}

\begin{abstract}
The mononuclear iron complex $1, \mathrm{Fe}^{\mathrm{III}}(\mathrm{Hbida}) \mathrm{Cl}\left(\mathrm{H}_{2} \mathrm{O}\right)$, was synthesized using a tripodal tetradentate ligand, $N$-(benzimidazol-2-ylmethyl)iminodiacetic acid $\left(\mathrm{H}_{5}\right.$ bida), which has two carboxylate groups, one benzimidazoyl group, and one tertiary amine where it serves as a tetradentate chelating ligand for the octahedral $\mathrm{Fe}$ (III) ion. The four equatorial positions of the octahedral complex are occupied by two monodentate carboxylates, a benzimidazole nitrogen, and an oxygen of a water molecule. One of the axial positions is occupied by an apical nitrogen of the Hbida and the other by a chloride anion. The mononuclear octahedral complex 1 mimics the geometry of the key intermediate structure of the catalytic reaction cycle proposed for the FeSODs, which is a distorted octahedral geometry with three histidyl imidazoles, an aspartyl carboxylate, a superoxide anion, and a water molecule. The redox potential of complex $1, \mathrm{E}_{12}$ is $-0.1 \mathrm{~V} v \mathrm{vs}$. Ag/ $\mathrm{AgCl}(0.12 \mathrm{~V} v \mathrm{~s}$. NHE), which is slightly lower than those reported for the most FeSODs. The magnetic susceptibility of complex $\mathbf{1}$ at room temperature is $5.83 \mu_{3}$ which is close to that of the spin only value, $5.92 \mu_{3}$ of high-spin $\mathrm{d}^{5} \mathrm{Fe}$ (III).
\end{abstract}

Key Words : Iron(III) complex, Superoxide dismutase, Tripodal tetradentate ligand, Biomimetic

\section{Introduction}

The modeling studies that mimic the active sites of metalloenzymes are important for understanding the reaction mechanism of the metalloproteins and for developing small molecular weight biomimetic catalysts. ${ }^{1}$ The superoxide dismutases (SODs) are metalloenzymes that catalyze the disproportionation of superoxide to water or hydrogen peroxide, and play a key role in protecting aerobic cells against oxidative damage through a cyclic oxidation-reduction mechanism. ${ }^{2}$ Even though many low molecular weight SOD mimics were reported earlier, ${ }^{3}$ most of them were not based on the active site structures of $\mathrm{Fe}-,{ }^{4} \mathrm{Mn}-{ }^{5}{ }^{5} \mathrm{Cu} / \mathrm{Zn}-{ }^{6}$ and Ni-SOD. ${ }^{7}$ Only a few biomimetic SOD mimics were synthesized by using ligands that have similar donor environments present in the $\mathrm{Fe}^{-}{ }^{8}$ and $\mathrm{Mn}-\mathrm{SOD}^{9}$ active sites. The intermediate state of the Fe-SOD active site contain a superoxide ligated to the metal center increasing the coordination number from five to six. The geometry of intermediate state structure of the proposed catalytic reaction cycle of Fe-SOD is assumed to be a distorted octahedral coordination environment composed of three oxygen and three nitrogen atoms provided by three histidyl imidazoles, an aspartyl carboxylate, a superoxide, and a water molecule. ${ }^{10}$

Recently, we reported a mononuclear Fe(III) complex containing a tripodal tetradentate ligand, tris(2-benzimidazolylmethyl)amine (ntb), $\left[\mathrm{Fe}^{\mathrm{III}}(\mathrm{ntb}) \mathrm{Cl}_{2}\right] \mathrm{ClO}_{4},{ }^{11 \mathrm{a}}$ which do not have oxygen donor atoms, and has only four nitrogen atoms of $\mathrm{H}_{3}$ ntb and two chloride anions. The redox potential of the complex is slightly higher than the values known for Fe-SODs ${ }^{21}$ The Fe(III)/Fe(II) redox reaction in dmf is quasi- reversible and occurs at $+0.25 \mathrm{~V}\left(\mathrm{E}_{1 / 2}\right)(0.48 \mathrm{~V} v$ s. $\mathrm{NHE})$. In this study, we modified the tripodal tetradentate ligand ntb, containing three benzimidazole groups, into $\mathrm{H}_{3}$ bida containing one benzimidazole group and two carboxylic acid groups; synthesized and characterized a mononuclear high spin Fe(III) complex with a biomimetic tripodal tetradentate ligand, $N$-(benzimidazol-2-ylmethyl)iminodiacetic acid $\left(\mathrm{H}_{3}\right.$ bida) that has two nitrogen and two oxygen donor atoms.

\section{Experiment Section}

Materials. The following commercially available chemicals were purchased and used without further purification: $\mathrm{Fe}$ (III) chloride hexahydrate from Aldrich Inc.; methanol from Junsei. $N$-(Benzimidazol-2-ylmethyl)iminodiacetic acid $\left(\mathrm{H}_{3}\right.$ bida) was prepared according to literature procedure. ${ }^{12}$

Instrumentations. Elemental analysis was performed at the Elemental Analysis Laboratory of Korean Basic Science Institute on a CE Flash EA 1112 series elemental analyzer. Infrared spectra were recorded as $\mathrm{KBr}$ pellets in the range $4000-400 \mathrm{~cm}^{-1}$ on a Bio-Rad FT-IR spectrometer. Thermogravimetric analysis was performed on a Scinco Simultaneous Thermal Analyzer (STA) S-1000 thermal analyzer under a stream of $\mathrm{N}_{2}$ with a heating rate of $10^{\circ} \mathrm{C} / \mathrm{min}$ between ambient temperature and $500^{\circ} \mathrm{C}$. Room temperature magnetic susceptibility of well ground solid sample was measured by using an Evans balance. The measurement was calibrated against $\mathrm{Hg}-\left[\mathrm{Co}(\mathrm{SCN})_{4}\right]$ standard. ${ }^{13}$

Synthesis. Fe $\mathrm{e}^{\text {III }}$ (Hbida) $\mathrm{Cl}\left(\mathrm{H}_{2} \mathrm{O}\right), 1$. A $0.16 \mathrm{~g}(0.62 \mathrm{mmol})$ amount of $\mathrm{H}_{3}$ bida was dissolved in $30 \mathrm{~mL}$ of methanol. Then a $0.17 \mathrm{~g}(0.63 \mathrm{mmol})$ amount of $\mathrm{Fe}$ (III) chloride 
hexahydrate was added to the solution. The solution was stirred till the solution become clear, it was allowed to stand for 7 days, when orange crystals separated out of the solution $\left(0.12 \mathrm{~g}, 54.5 \%\right.$ yield). Anal. Calcd for Fe $\mathrm{F}^{\text {III }}$ (Hbida)$\mathrm{Cl}\left(\mathrm{H}_{2} \mathrm{O}\right)\left(\mathrm{FeC}_{12} \mathrm{H}_{15} \mathrm{~N}_{3} \mathrm{O}_{6} \mathrm{Cl}\right)$ (fw 281.27): $\mathrm{C} 36.98 \mathrm{H} 4.05 \mathrm{~N}$ 10.46. Found: C $37.09 \mathrm{H} 3.89 \mathrm{~N}$ 10.81. IR $\left(\mathrm{cm}^{-1}\right): 3570.9$ (w), 3380.8 (br), 3198.4 (br), 3115.0 (w), 3055.6(w), 2976.2 (w), $2928.5(\mathrm{w}), 2849.3$ (br), $2781.8(\mathrm{w}), 2639.1$ (w), 1742.7 (w), $1635.8(\mathrm{w}), 1620.5(\mathrm{w}), 1492.3(\mathrm{w}), 1475.9(\mathrm{~s}), 1475.7$ (s), $1447.9(\mathrm{w}), 1428.4(\mathrm{w}), 1393.2(\mathrm{w}), 1377.4(\mathrm{~m}), 1344.7$ (m), $1319.0(\mathrm{w}), 1282.6(\mathrm{~s}), 1230.3(\mathrm{~s}), 1208.4(\mathrm{~m}), 1152.5$ (m), 1120.9 (w), 1108.7 (w), 1049.1 (s), $1007.7(\mathrm{w}), 1000.5$ $(\mathrm{w}), 968.8(\mathrm{~s}), 936.0(\mathrm{~s}), 919.0(\mathrm{~s}), 903.2(\mathrm{w}), 861.9(\mathrm{w})$, $753.7(\mathrm{~m}), 743.9(\mathrm{w}), 723.2(\mathrm{w}), 677.1(\mathrm{~m}), \mu_{\mathrm{eir}}=5.83 \mu_{\mathrm{B}}$. $\mathrm{E}_{1 / 2}=-0.11 \mathrm{~V} v s . \mathrm{Ag} / \mathrm{AgCl}(0.12 \mathrm{~V} v s . \mathrm{NHE})$.

X-ray Crystallography. The crystal was coated with paratone oil to prevent loss of crystallinity on exposure to air. The data collection was performed at $-100^{\circ} \mathrm{C}$ with $\mathrm{Mo}$ $\mathrm{K} \alpha$ radiation $(\lambda=0.71073 \AA)$ on a Bruker SMART CCD equipped with a graphite crystal, incident-beam monochromator. The SMART and SAINT software packages ${ }^{1+}$ were used for data collection and integration, respectively. The collected data were corrected for absorbance using SADABS ${ }^{15}$ based upon Laue symmetry using equivalent reflections. Structures were solved by direct methods and refined by full-matrix least-squares calculations with the SHELXTLPLUS software package. ${ }^{16}$ All non-hydrogen atoms were refined anisotropically; hydrogen atoms were found by difference Fourier peaks, and refined isotropically. The methyl protons of free methanol solvent molecule was

Table 1. Crystal structure and refinement data for 1

\begin{tabular}{ll}
\hline Empirical formula & $\mathrm{FeC}_{13} \mathrm{H}_{17} \mathrm{~N}_{3} \mathrm{O}_{6} \mathrm{Cl}$ \\
Formula weight & 402.60 \\
Temperature & $173(2) \mathrm{K}$ \\
Crystal system, space group & Orthorhombic, $P b c a$ \\
Unit cell dimensions & $\mathrm{a}=13.718(2) \AA$ \\
& $\mathrm{b}=14.243(2) \AA$ \\
& $\mathrm{c}=17.235(3) \AA$ \\
Volume & $3367.6(9) \AA^{1}$ \\
Z, Calculated density & $8,1.588 \mathrm{mg}^{3} / \mathrm{m}^{3}$ \\
Absorption coefficient & $1.088 \mathrm{~mm}^{-1}$ \\
Reflections collected $/$ unique & $19525 / 4064[\mathrm{R}(\mathrm{int})=0.0261]$ \\
Final R indices [I>2 $\sigma(\mathrm{I})]$ & $\mathrm{R} 1=0.0407, \mathrm{wR} 2=0.1118$ \\
R indices (all data) & $\mathrm{R} 1=0.0590, \mathrm{wR} 2=0.1257$ \\
\hline
\end{tabular}

assigned isotropic displacement coefficients $U(\mathrm{H})=1.5 U$ (C-methyl) and its coordinates were allowed to ride on respective atoms. Crystal and intensity data are given in Table 1.

Electrochemistry. Electrochemical measurement was performed on a BAS CV-50W under argon atmosphere in a conventional three-electrode cell consisting of $\mathrm{Ag} / \mathrm{AgCl}$ ( 3 $\mathrm{M} \mathrm{KCl}$ ) reference electrode, $\mathrm{Pt}$ wire counter electrode and a glassy carbon working electrode. The glassy carbon electrode was polished freshly using alumina before each scan. A solution of the complex in $\mathrm{dmf}\left(\sim \mathrm{mmol} / \mathrm{dm}^{3}\right)$ was used for recording cyclic voltammogram of the complex 1 with tetrabutylammonium tetrafluoroborate $\left(\left[\mathrm{CH}_{3}\left(\mathrm{CH}_{2}\right)_{3}\right]_{4} \mathrm{NBF}_{4}\right)$ of $0.1 \mathrm{~mol} / \mathrm{dm}^{3}$ as the supporting electrolyte.

\section{Results and Discussion}

Preparation and Characterization of Complex 1 . $\mathrm{Fe}^{\mathrm{III}}(\mathrm{Hbida}) \mathrm{Cl}\left(\mathrm{H}_{2} \mathrm{O}\right), 1$ can be synthesized using $\mathrm{Fe}$ (III) chloride as a metal source and Hbida ${ }^{2-}$ as a dianionic tripodal tetradentate ligand with two carboxylates and one benzimidazolyl group. (Scheme 1) The mononuclear Fe(III) complex (1) has octahedral geometry. The magnetic moment of complex 1 at room temperature, $5.83 \mu_{\mathrm{B}}$, is comparable to the spin-only value of high spin $\mathrm{d}^{5} \mathrm{Fe}(\mathrm{III}), 5.92 \mu_{\mathrm{B}}$.

Molecular Structure of Complex 1. An ORTEP drawing of complex 1 is shown in Figure $1 . \mathrm{H}_{3}$ bida behaves as a tetradentate ligand that has two methylcarboxylate groups and a benzimidazolylmethyl group extending from central tertiary amine nitrogen. The four equatorial coordination positions of the $\mathrm{Fe}(\mathrm{III})$ complex are occupied by two oxygen atoms (O1, O3) of carboxylates, a nitrogen atom (N2) of benzimidazole in the $\mathrm{Hbida}^{2-}$ and an oxygen atom (O5) of the water molecule. One of the axial positions is occupied by apical nitrogen $(\mathrm{NI})$ of the $\mathrm{Hbida}^{2-}$ and the other by a chloride (Cl1) anion. Complex 1 has mononuclear octahedral geometry. The complex $\mathbf{1}$ is neutral, as the ligand $\mathrm{Hbida}^{2-}$ is dianionic due to two deprotonated carboxylate group and a protonated amine (N3) of the benzimidazoyl group. The geometry of the complex 1 is very similar to that of the $\mathrm{Fe}(\mathrm{III})$ complex of ntb ([ $\left.\left.\mathrm{Fe}^{\mathrm{III}}(\mathrm{ntb}) \mathrm{Cl}_{2}\right] \mathrm{ClO}_{4}\right)^{1 \mathrm{tol}}$ except that the two of the basal nitrogen atoms of the benzimidazoyl groups are replaced by the oxygen atoms of the carboxylic groups.

The average bond distance between the $\mathrm{Fe}$ (III) ion and the two basal oxygen atoms of carboxyl groups is $1.995 \AA$

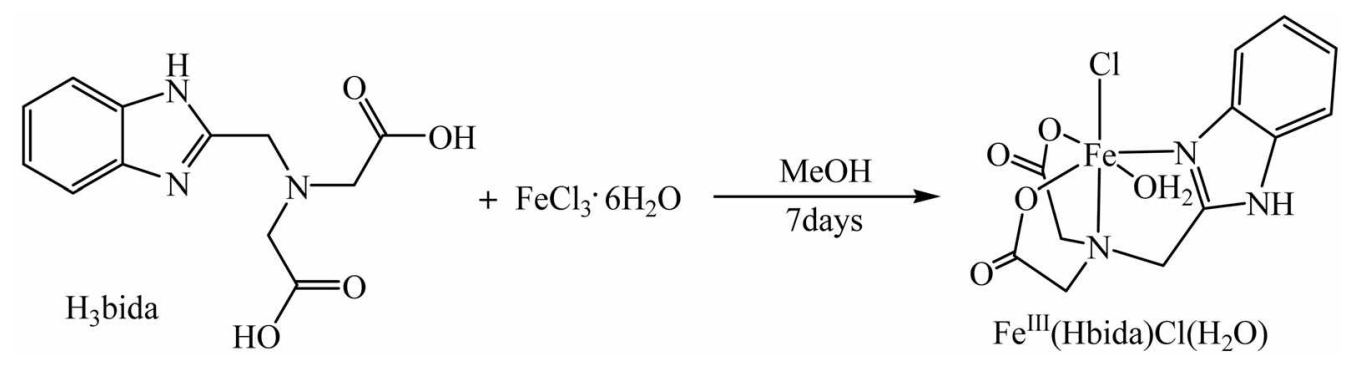

Scheme 1. Reaction scheme for $\mathrm{Fc}^{m}$ (Hbida)Cl( $\left.\mathrm{H}_{2} \mathrm{O}\right), 1$. 


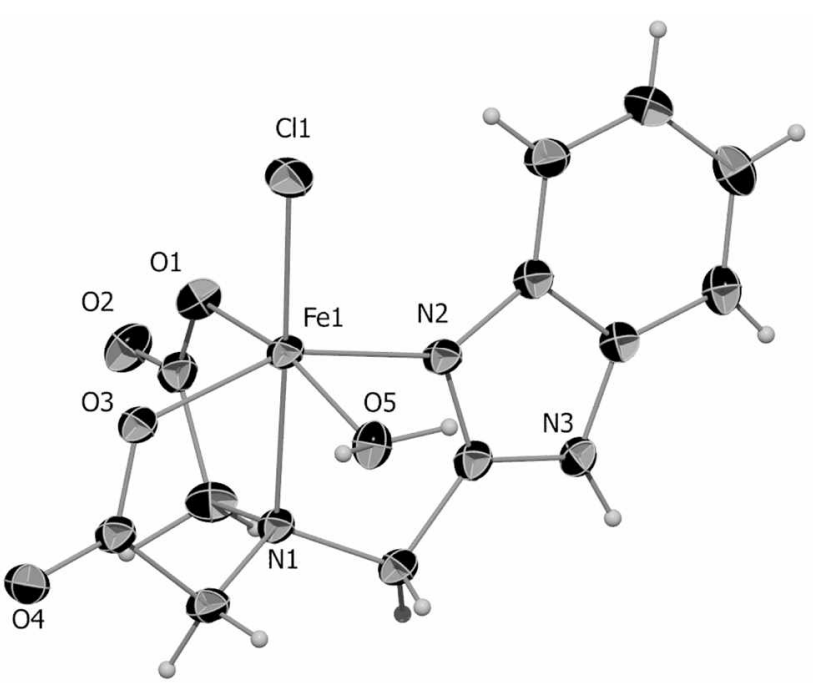

Figure 1. ORTEP drawing ( $30 \%$ ) of $\mathrm{Fe}^{\mathrm{mI}}(\mathrm{Hbida}) \mathrm{Cl}\left(\mathrm{H}_{2} \mathrm{O}\right)$, 1. Both carboxylic protons were deprotonated and one amine proton of the benzinidazoyl group was protonated and the ligand served as dianionic Hbida ${ }^{2-}$.

Table 2. Selected Bond Distances $(\AA)$ and Angles $\left({ }^{\circ}\right)$ for 1

\begin{tabular}{lclr}
\hline $\mathrm{Fe}(1)-\mathrm{O}(1)$ & $1.990(2)$ & $\mathrm{Fe}(1)-\mathrm{Cl}(1)$ & $2.2431(8)$ \\
$\mathrm{Fe}(1)-\mathrm{O}(3)$ & $2.0002(18)$ & $\mathrm{Fe}(1)-\mathrm{N}(1)$ & $2.255(2)$ \\
$\mathrm{Fe}(1)-\mathrm{O} 5$ & $2.047(2)$ & $\mathrm{Fe}(1)-\mathrm{N}(2)$ & $2.080(2)$ \\
& & & \\
O(1)-Fe(1)-O(3) & $90.34(8)$ & $\mathrm{O}(5)-\mathrm{Fe}(1)-\mathrm{Cl}(1)$ & $96.02(7)$ \\
$O(3)-\mathrm{Fe}(1)-\mathrm{O}(5)$ & $86.21(9)$ & $\mathrm{N}(2)-\mathrm{Fe}(1)-\mathrm{Cl}(1)$ & $104.51(7)$ \\
$O(1)-\mathrm{Fe}(1)-\mathrm{O}(5)$ & $166.50(9)$ & $\mathrm{O}(1)-\mathrm{Fe}(1)-\mathrm{N}(1)$ & $80.89(8)$ \\
$O(1)-\mathrm{Fe}(1)-\mathrm{N}(2)$ & $90.59(8)$ & $\mathrm{O}(3)-\mathrm{Fe}(1)-\mathrm{N}(1)$ & $77.24(7)$ \\
$O(3)-\mathrm{Fe}(1)-\mathrm{N}(2)$ & $153.20(8)$ & $\mathrm{O}(5)-\mathrm{Fe}(1)-\mathrm{N}(1)$ & $85.62(8)$ \\
$O(5)-\mathrm{Fe}(1)-\mathrm{N}(2)$ & $86.69(9)$ & $\mathrm{N}(2)-\mathrm{Fe}(1)-\mathrm{N}(1)$ & $76.47(8)$ \\
$O(1)-\mathrm{Fe}(1)-\mathrm{Cl}(1)$ & $97.46(6)$ & $\mathrm{Cl}(1)-\mathrm{Fe}(1)-\mathrm{N}(1)$ & $178.12(6)$ \\
$O(3)-\mathrm{Fe}(1)-\mathrm{Cl}(1)$ & $101.92(6)$ & & \\
\hline
\end{tabular}

$(1.990,2.000 \AA)$. The bond distance between the Fe(III) ion and the chloride anion at the trans position of the apical tertiary nitrogen atom is $2.243 \AA$. The bond distance between the Fe(III) ion and the apical chloride is very close, $2.240 \AA$ of the $\left[\mathrm{Fe}(\mathrm{Hbbea}) \mathrm{Cl}_{2}\right]^{+}$complex, ${ }^{114}$ and about 0.03 $\AA$ longer than that in $\left[\mathrm{Fe}(\mathrm{ntb}) \mathrm{Cl}_{2}\right] \mathrm{ClO}_{4}$ complex. ${ }^{1{ }^{1 / a}}$ The bond distance between the $\mathrm{Fe}$ (III) ion and the apical nitrogen atom (N1) of $2.255 \AA$ is about $0.15 \AA$ longer than $2.105 \AA$ of the general distance between $\mathrm{Fe}(\mathrm{III})$ ion and the basal nitrogen atom of benzimidazoyl group. The bond distance between the $\mathrm{Fe}(\mathrm{III})$ ion and the basal nitrogen $(\mathrm{N} 2)$ atom of benzimidazolyl group is $2.080 \AA$. The bond distance between the Fe(III) ion and the oxygen atom of the water molecule is $2.047 \AA$. These bond distances are summarized in Table 2 . Crystallographic data for the structure reported here have been deposited with Cambridge Crystallographic Data Center (Deposition No. CCDC 606115). The data can be obtained free of charge via http://www.ccdc.cam.ac.uk/perl/catreg.cgi (or from the CCDC, 12 Union Road, Cambridge CB2 1EZ, UK; fax: +44 1223 336033; e-mail: deposit@ccdc.cam.ac. uk).

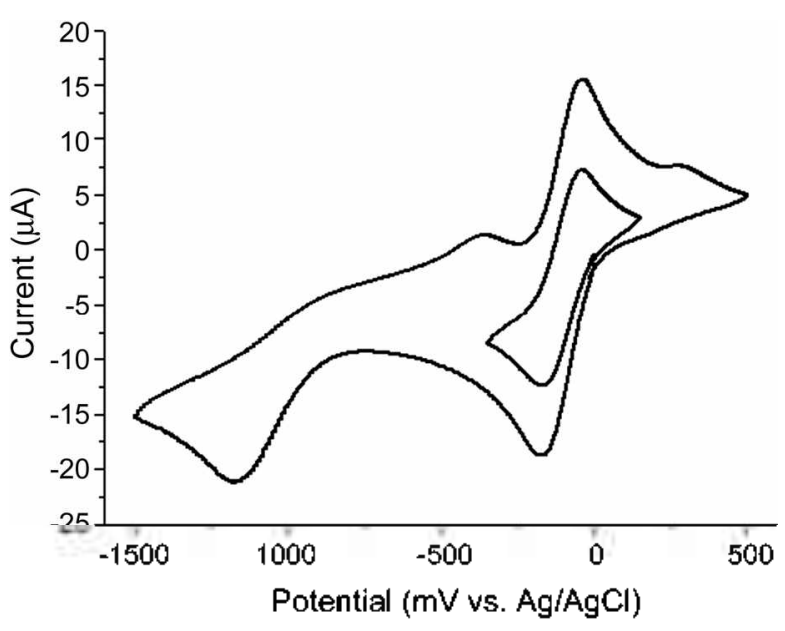

Figure 2. Cyclovoltamogram for $\mathrm{Fe}^{\mathrm{mI}}(\mathrm{Hbida}) \mathrm{Cl}\left(\mathrm{H}_{2} \mathrm{O}\right), 1$.

Electrochemical Property. The redox potential of $\left[\mathrm{Fe}(\mathrm{ntb}) \mathrm{Cl}_{2}\right]^{+}$prepared using a neutral tripodal tetradentate ligand tris(2-benzimidazolylmethyl)amine (ntb), $+0.25 \mathrm{~V}$ $\left(E_{1: 2}\right)\left(0.48 \mathrm{~V} v \mathrm{~s}\right.$. NHE) ${ }^{11 \mathrm{a}}$ was reported to be slightly higher than those of the native FeSODs, $-0.03 \sim+0.17 \mathrm{~V}\left(E_{1 / 2}\right)(0.2$ $\sim 0.4 \mathrm{~V}$ vs. NHE) $)^{2 \mathrm{r}}$. The $\mathrm{Fe}(\mathrm{III}) / \mathrm{Fe}$ (II) redox reaction of complex 1 is quasi-reversible and occurs at $-0.11 \mathrm{~V}\left(E_{1 / 2}\right)$ $(0.12 \mathrm{~V} v s$. NHE), as shown in Figure 2. However, this value is a slightly lower than those of the native FeSODs. The introduction of two negatively charged carboxylate groups shifts the redox potential of complex 1 to the negative direction. It may possible to tune the redox potential of the model complex via the control of the charge of the ligand used.

Thermal Analysis. The weight loss of about $2.34 \%$ (calcd $2.37 \%$ ) below $90^{\circ} \mathrm{C}$ in the TGA of complex 1 corresponds to the loss of half of free water molecule per unit cell. The second loss corresponding to the release of the coordinated water molecule is detected between 90 and $130^{\circ} \mathrm{C}$ (obsd $5.02 \%$, calcd $4.89 \%$ ). The decomposition temperature for 1 was observed to be about $200^{\circ} \mathrm{C}$. The total destruction of the complex by the oxidation of the organic component, finally leaves stoichiometric amount of iron oxide as the residues (obsd 20.70\%, calcd 18.98\%). (Figure 3)

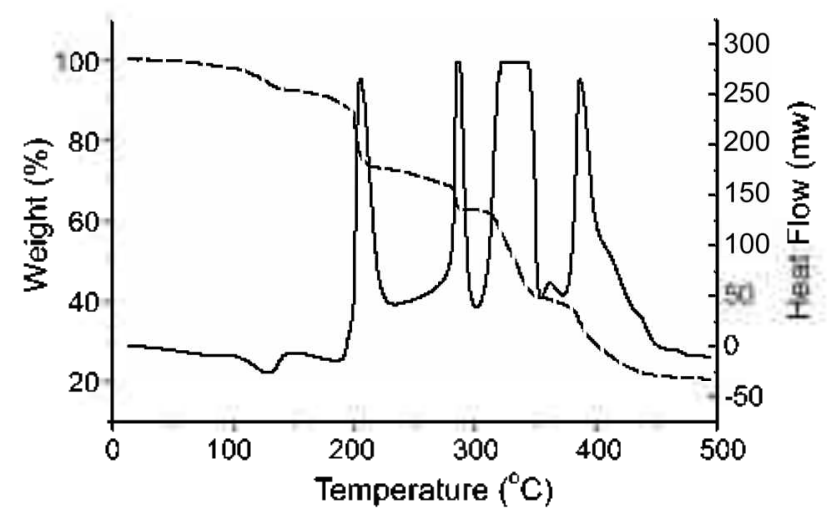

Figure 3. TG/DSC curves for $\mathrm{Fe}^{\mathrm{IT}}(\mathrm{Hbida}) \mathrm{Cl}\left(\mathrm{H}_{2} \mathrm{O}\right)$, 1. Dashed line is for the TG curve, solid line for the DSC curve. 
In conclusion, we have synthesized and characterized a mononuclear high spin Fe(III) complex containing a biomimetic dianionic tripodal tetradentate ligand, $\mathrm{Hbida}^{2-}$ which has two carboxylate groups and one benzimidazoyl group. Two of the basal positions of the octahedral Fe(III) complex are occupied by the oxygen atoms of two monodentate carboxylate groups in cis-configuration, and the remaining basal positions by a nitrogen atom of the benzimidazoyl group and an oxygen atom of the water molecule. One of the axial positions of the complex is occupied by an apical tertiary nitrogen atom of the ligand, and the remaining site by a chloride anion. The redox potential of complex 1 is slightly lower than those of the native Fe-SODs. To tune the redox properties of the SOD mimetics, we may need to control the charge of the ligand used. The ligand with two benzimidazoyl groups and one carboxyl group might lead to the complex with proper redox properties for FeSOD mimetics.

Acknowledgment. We thank the Korea Basic Science Institute for elemental analysis. Authors wish to acknowledge the financial support of KOSEF (R01-2005-000$10490-0)$ and Hanyang University (2005).

\section{References}

1. Fridovich, I. Ammt. Rev: Biochem. 1992, 64, 97-112.

2. (a) Jackson, T. A.; Brunold, T. C. Acc. Chem. Res, 2004, 37, 461470. (b) Fridovich, I. J. Biol. Chem. 1989, 264, 776l-7764. (c) Knidenier, L.; Verspaget, H. W, Alinent Parm. Therp. 2002, 16 , 1997-2015. (d) Riley, D. P. Chem, Rev: 1999, 99, 2573-2587. (e) Clay, M. D.; Cosper, C. A.; Jenney, Jr. F. E.; Adams, M. W. W.; Johnson, M. K. PNAS 2003, 100, 3796-380I. (f) Vance, C. K.; Mikker, A.-F. J. Ant. Chem. Soc. 1998, $120,461-467$. (g) Hunter, T.; Bannister, J. V.; Hunter, G. J. Evr. J. Biochem. 2002, 260, 5137 5148. (h) Beyer, W. F.; Reynolds, J. A.; Fridovich, I. Biochemistry $1989,28,4403-4409$.

3. (a) Fiedler, A. T.; Halfen, H. L.; Halfen, J. A.; Brunold, T. C. J. Am. Chem. Soc, 2005, 127, 1675-1689. (b) Halfen, J. A.; Moore, H. L.; Fox, D. C. Inorg. Chem. 2002, 41, 3935-3943. (c) Brewer, C. T.; Brewer, G.; Shang, M.; Scheidt. W. R.; Muller, I. Inorg. Chim. Acta 1998, 278, 197-20l. (d) Govindaswamy, N.; Quarless, Jr. D. A.; Koch, S. A. J. Am. Chem. Soc. 1995, $117,8468-8469$. (e) Buchanan, R. M.; O'Brien, R. J.; Richardson, J. F. Inorg. Chim. Acta 1993, 214, 33-40. (1) Durot, S.; Lambert, F.; Renault, J.-P.; Policar, C. Eur. J. Inorg. Chem. 2005, 2789-2793. (g) Salvemini, D.; Muscoli, C.; Riley, D. P.; Cuzzocrea, S. Puln. Pharnacol. Ther: 2002, 15, 439-447. (h) Riley, D. P,; Weiss, R. H. J. Am. Chent. Soc. 1994, 116, 387-388. (i) Kitajima, N.; Osawa, M.; Tamura, N.; Moro-oka, Y.; Hirano, T.; Hirobe, M.; Nagano, T. lhorg. Chem. 1993, 32, 1879-1880.

4. (a) Yikilmaz, E.; Rodgers, D. W.; Miller, A.-F. Biochemistry 2006, 45, 1151-1161. (b) Dufernez, F.; Yernaux, C.; Gerbod, D.; Nö̈l, C.; Chauvenet M.; Wintiens, R.; Edgcomb, V. P.; Capron, M.; Opperdoes, F. R.; Viscogliosi, E. Free Radical Bio. Med. 2006, 40, 210-225. (c) Muñoz, I. G; Moran, J. F.; Becana, M.; Montoya, G Protein Sci. 2005, 14, 387-394. (d) Balland, V.; Banse, F.; Anxolavéhère-Mallart, E.; Ghiladi, M.; Mattioli, T. A.; Philouze, C.; Blondin, G.; Girerd, J.-J. Inorg. Chem. 2003, 42, 2470-2477. (e) Clay, M. D.; Jenney, Jr. F. E.; Noh, H. J.; Hagedoom, P. L.; Adams, M. W. W; Johnson, M. K. Biochemistry 2002, 41, 9833984 I. (†) Tiemey, D. L.; Fee, J. A.; Ludwig, M. L.; Penner-Hahn,
J. E. Biochemistry 1995, 34, 1661-1668.

5. (a) Bruno-Bárcena, J. M.; Andrus, J. M.; Libby, S. L.; Klaenhammer, T. R.; Hassan, H. M. Appl. Enniron. Microbiol. 2004, 70, 4702-4710. (b) Wang. Y.; Ying. Y.; Chen, J.; Wang, X. Plant Sci. 2004, 167, 671-677. (c) Piacham, T; Na Ayudhya, C. I.; Prachayasittikul, V.; Bülow, L.; Ye, L. Chem. Commmin. 2003, 1254-1255. (d) Edwards, R. A.; Baker, H. M.; Whitlaker, M. M.; Whittaker, J. W.; Jameson, G. B.; Baker, E. N. J. Biol. Inorg, Chen. 1998, 3, 161-171. (e) Benov, L.; Fridovich, I. Arch. Biochen. Biophys. 1995, 322, 291-294.

6. (a) Bijeire, L.; Elias, B.; Souchard, J.-P.; Gicquel, E.; Moucheron, C.; Mesmaeker, A. K.-D.; Vicendo, P. Biochemistry 2006, 45, 6160-6169. (b) Kim, N. H.; Jeong. M. S.; Choi, S. Y.; Kang. J. H. Biochinie 2004, 86, 553-559. (c) Jensen, L. T.; Sanchez, R. J.; Srinivasan, C.; Valentine, J. S.; Culotta, V. C. J. Biol. Chem. 2004, 279, 29938-19943. (d) Ge, B.; Sheller, F. W; Lisdat, F. Biosens. Bioelectron. 2003, 18, 295-302. (e) Ohisu, H.; Shimazaki, Y; Odani, A.; Yamauchi, O.; Mori, W; Itoh, S.; Fukuzumi, S. J. Am. Chem. Soc. 2000, 122, 5733-5741. (f) Yoon, S. J.; Koh, Y. H.; Floyd, R. A.; Park, J.-W. Mut. Res. 2000, 448, 97-104.

7. (a) Ahn, B.-E.; Cha, J.; Lee, E.-J.; Han, A.-R.; Thompson, C. J.; Roe, J.-H, Molectlar Microbiolog: 2006, 59, 1848-1858. (b) Barondeau, D. P.; Kassmann, C. J.; Bruns, C. K.; Tainer, J. A.; Getzoff, E. D. Biochemistry 2004, 43, 8038-8047. (c) Choudhury, S. B.; Lee, J.-W.; Davidson, G; Yim, Y.-I.; Bose, K.; Sharma, M. L.; Kang, S.-O.; Cabelli, D. E.; Maroney, M. J. Bicchemistry $1999,38,3744-3752$.

8. (a) Carvalho, N. M. F.; Horn Jr., A.; Bortoluzzi, A. J.; Drago, V.; Antunes, O. A. C. Inorg. Chim. Acta 2006, 359, 90-98. (b) Tamura, M.; Urano, Y.; Kikuchi, K.; Higuchi, T.; Hirobe, M.; Nagano, T. J. Organomet. Chem. 2000, 611, 586-592. (c) Zhang, D.; Busch, D. H.; Lennon, P. L.; Weiss, R. H.; Neumann, W. L.; Riley, D. P. Inorg. Chem. 1998, 37, 956-963. (d) Nishida. Y.; Watanabe, I.; Unoura. K. Chem. Letf. 1991, 1517-1520.

9. (a) Durot, S.; Policar, C.; Cisnetti, F.; Lamvert, F.; Renault, J.-P.; Pelosi, G; Blain, G; Korri-Youssoufi, H.; Mahy, J.-P. Eur. J. Inorg. Chem. 2005, 3513-3523. (b) Lewis, E. A.; Khodr, H. H.; Hider, R. C.; Smith, J. T. L.; Walton, P. H. Dalton Trans. 2004 , 187-188. (c) Aston, K.; Rath, N.; Naik, A.; Slomczynska, U.; Schall, O. F.; Riley, D. P. Inorg. Chem. 2001, 40, 1779-1789. (d) Riley, D. P.; Lennon, P. J.; Neumann, W. L.; Weiss, R. H. J. Am. Chem. Soc. 1997, 119, 6522-6528. (e) Deroche, A.; MorgensternBadarau, I.; Cesario, M.; Guilhem, J.; Keila, B.; Nadjo, L.; Houée-Levin, C. J. An. Chem. Soc. 1996, II8, 4567-4573. (f) Riley, D. P.; Henke, S. L.; Lennon, P. J.; Weiss, R. H.; Neumann, W. L.; Rivers, Jr. W. J.; Aston, K. W.; Sample, K. R.; Rahman, H.; Ling, C.-S.; Shieh, J.-J.; Busch, D. H.; Szulbinski, W. Inorg. Chem. 1996, 35, 5213-5231.

10. (a) Lah, M. S.; Dixon, M. M.; Pattridge, K. A.; Stallings, W. C.; Fee, J. A.; Ludwig. M. L. Biochemistry 1995, 34, 1646-1660. (b) Miller, A.-F.; Sorkin, D. L.; Padmakumar, K. Biochemistry 2005 , 44, 5969-5981. (c) Schwartz, A. L.; Yililmaz, E.; Vance, C. K.; Vahyam, S.; Koder, R. L.; Miller, A.-F. J. Inorg. Biochem. 2000, $80,247-256$.

11. (a) Kwak, B.; Cho, K. W.; Pyo, M.; Lah, M. S. Inorg. Chim. Acta 1999, 290, 21-27. (b) Kwak, B.; Rhee, H.; Lah, M. S. Bull. Korean Chem. Soc. 1999, 20, 1235-1237.

12. (a) Cescon, L. A.; Day, A. R. J. Org. Chem. 1962, 27, 581-5860. (b) Wilson, J. G.; Hunt, F. C. Atst. J. Chem. 1983, 36, 2317-2325.

13. Evans, D. F. J. Chem. Soc. 1958, 2003-2005.

14. SMART and SANT, Area Detector Sofware Package and SAX Area detector Integration Program; Bruker Analytical X-ray: Madison, WI, 1997.

15. SADABS, Area Detector Absorption Correction Program; Bruker Analylical X-ray: Madison, WT, 1997.

16. Sheldrick, G. M. SHELITL-PLUS, Crystal Structure Analysis Package; Bruker Analylical X-ray: Madison, WI, 1997. 